$\underline{\text { Artikel Penelitian }}$

\title{
Antidiabetic Effect of Urena lobata: Preliminary Study on Hexane, Ethanolic, and Aqueous Leaf Extracts
}

\section{Efek Antidiabetes dari Urena lobata: Studi Pendahuluan pada Ekstrak Daun dengan Pelarut Heksan, Etanol, dan Air}

\author{
Doti Wahyuningsih"1, Yudi Purnomo ${ }^{2}$ \\ ${ }^{1}$ Laboratorium Biokimia Fakultas Kedokteran Universitas Islam Malang \\ ${ }^{2}$ Laboratorium Pharmakologi Fakultas Kedokteran Universitas Islam Malang
}

\begin{abstract}
Chronic hyperglycemia is one of the signs of human type-2 diabetes mellitus due to insulin resistance and depletion. This study aimed to evaluate hexane, ethanolic, and aqueous leaf extracts of Urena lobata as antihyperglycemic agent. Design of this study was a post-test only control group using 25 male Sprague-Dawley rats divided into 5 groups. High fructose diet (HFD) ad libitum and single dose of intraperitoneal streptozocin (STZ) (25 mg/kgBW) were administered to induce diabetes in rats. Three groups of the diabetic rats orally received $500 \mathrm{mg} / \mathrm{kgBW}$ of only a type of leaf extract of U. lobata for 4 weeks. Insulin serum levels were measured using enzyme-linked immunosorbent assay (ELISA) method. Size, shape, and density of the islet cells were observed by light microscope. Blood glucose level and the area under curve (AUC) of serial oral glucose tolerance test (OGTT) were measured. The U. lobata leaf extracts of three types of solvent all increased serum insulin level and improved $B$ cells condition, also decreased the AUC of the OGTT series in diabetic rats. Values were compared with untreated diabetic rats $(p<0,05)$. The aqueous leaf extract of $U$. lobata was the best in increasing insulin serum level, recovering islet cells condition, and correcting blood glucose level. The hexane extract showed poor results when compared to the other soluble agents.
\end{abstract}

Keywords: Urena lobata, hyperglycemia, diabetic rats, insulin, aqueous extract

\section{ABSTRAK}

Hiperglikemia kronis adalah salah satu gejala dari diabetes mellitus (DM) tipe-2 yang disebabkan oleh kekurangan jumlah dan keadaan resistansi insulin. Penelitian ini bertujuan untuk mengevaluasi efek antihiperglikemia daun Urena lobata yang diekstrak dengan pelarut heksan, etanol, dan air. Desain penelitian adalah post-test only control group menggunakan 5 kelompok tikus Spraque-Dawley, setiap kelompok terdiri dari 5 ekor tikus. Tikus diabetes tipe-2 dibuat dengan memberikan high fructose diet (HFD) ad libitum dan streptozocin (STZ) single dose ( $25 \mathrm{mg} / \mathrm{kgBB}$ ) secara intraperitoneal. Tiga kelompok tikus diabetes menerima satu jenis ekstrak tertentu melalui mulut dengan dosis $500 \mathrm{mg} / \mathrm{KgBB}$ selama 4 minggu. Kadar insulin serum diukur menggunakan metode Enzyme-linked Immunosorbent Assay (ELISA). Gambaran sel $\beta$ pankreas dipelajari melalui mikroskop cahaya. Juga diukur area under curve (AUC) dari pengukuran serial oral glucose tolerance test (OGTT). Ekstrak daun U. lobata dari 3 jenis pelarut tersebut semuanya meningkatkan insulin serum dan memperbaiki gambaran sel $\beta$, juga menurunkan nilai AUC dari serial OGTT. Hasil ini dibandingkan dengan tikus diabetes tanpa perlakuan $(p<0,05)$. Ekstrak air $U$. lobata terbaik dalam meningkatkan insulin serum, memperbaiki gambaran sel $\beta$ dan kadar glukosa darah. Ekstrak heksan U. lobata memberikan hasil tidak sebaik 2 pelarut lain.

Kata Kunci: Urena lobata, hiperglikemia, tikus diabetes, insulin, ekstrak air

Korespondensi: Doti Wahyuningsih. Laboratorium Biokimia Fakultas Kedokteran Universitas Islam Malang, Jl. MT. Haryono 193-Malang Tel.(0341)558959Email: doti.wahyuningsih@gmail.com

DOI: http://dx.doi.org/10.21776/ub.jkb.xxxx.xxx.xx.x 


\section{INTRODUCTION}

Urena lobata otherwise called pulutan (JavaneseIndonesia) is shrub growing well in the paddy field of tropical region and growing well at elevations up to 1500 $\mathrm{m}$ above sea level (1). One hundred grams of raw leaf contain $81,8 \%$ moisture, 54 calories, $3,2 \mathrm{~g}$ of 57 protein, $0,1 \mathrm{~g}$ fat, $12,8 \mathrm{~g}$ carbohydrates, $1,8 \mathrm{~g}$ fiber, $2,1 \mathrm{~g}$ ash, $558 \mathrm{mg}$ calcium, and $67 \mathrm{mg}$ of phosphorous (2). Combination of $U$. lobata roots and Ennicostemma axillare (E. axillare) was reported to reduce spermatogenesis and steroidogenesis reversibly in adult male Wistar albino rats (3). Methanolic extract of $U$. lobata root at dose of $125-1000 \mu \mathrm{g} / \mathrm{ml}$ showed concentration-dependent antibacterial activity against some strains of Gram+ and Gram- (4). Root and leaf extracts of $U$. lobata have been used by Nigerian people to treat diabetes mellitus, a preclinical study of the plant root and leaf extract showed an anti-hyperglycemic effect on streptozocin (STZ) induced rats (5). Phytochemical screening of $95 \%$ ethanolic extract of aerial parts of the plant showed the presence of alkaloids, glycosides, steroids, tannins, saponins, and reducing sugars (6). Aqueous extract of $U$. lobata exhibited an inhibitory effect of dipeptidyl peptidase IV (DPP-IV) inhibiting glucagon like peptide-1 (7). Long-term administration (daily for 24 weeks) of aqueous extract of the plant roots toward weaned rabbits (New Zealand strain) was reported to protect the pancreas from oxidative stress (8). Ethanolic extract of the plant at a dose of $250 \mathrm{mg} / \mathrm{kgBW}$ exhibited antidepressant and antiinflammatory (9). This study examined the anti-diabetic effect of $U$. lobata leaf extracted by different solvents, namely; hexane, ethanol, and water.

\section{METHODS}

\section{Preparation of U. Lobata Leaf Extract}

The leaf powder was obtained from Balai Materia Medica, Batu, Malang with certificate No. 074/027/101.8/2015. Decoction method was used to obtain an aqueous extract. In brief, the powder $(50 \mathrm{~g})$ was extracted in $250 \mathrm{ml}$ of $90^{\circ} \mathrm{C}$ water for 30 minutes. Hexane and ethanolic extracts were prepared by using a shaking water bath at $40^{\circ} \mathrm{C}$ for 6 hours. The extracts were then evaporated to obtain concentrated extracts. The extraction was done at temperature below the boiling point of each solvent.

\section{Animals and Treatments}

Twenty five male Sprague-Dawley rats weighed 180-200g were obtained from Gadjah Mada University, Yogyakarta, Indonesia. The animals were maintained under the condition in accordance with the ethical clearance obtained from the Commission of Ethical Research of Brawijaya University, Malang, Indonesia, certificate No. 683-KEP-UB. The rats were separately housed into 5 groups and accommodated in an automatically controlled 12:12-hour-light-dark cycle room. Free access to food and water was available. Normal diet (ND) and high-fructose diet (HFD) were freshly prepared in a single alternate day. HFD contained $65 \%$ fructose and $35 \%$ ND. Intraperitoneal injection of a single dose $(25 \mathrm{mg} / \mathrm{kgBW})$ of STZ followed by free access to HFD were conducted to induce diabetes in rats (fasting blood glucose was more than $126 \mathrm{mg} / \mathrm{dL}$ ) (10), diabetic conditions were detected in most of the animals 4 weeks post-STZ injection. There were 4 diabetic groups and a group of normal rats (received only ND within the experiment). The diabetic rats continuously received HFD until the study ended. Three groups of the diabetic rats using gastric sonde received hexane extract (HEU), ethanolic extract (EEU), and aqueous extract (AEU) of $U$. lobata at a dose of $500 \mathrm{mg} / \mathrm{kgBW}$ every day for 4 weeks. Random and overnight fasting blood glucose level and oral glucose tolerance test (OGTT) were measured. Glucose at a dose of $2 \mathrm{~g} / \mathrm{kgBW}$ was orally administered prior to blood glucose measurement at $15,30,60$, and 120 minutes to present serial values of OGTT.

\section{Glucose and Insulin Detection}

Blood was taken from the tail vein. Blood glucose levels were measured by glucometer (Accu-Chek) (11). Intracardial blood was collected from ketalar anesthesia rats. Blood samples were immediately centrifuged at $4500 \mathrm{rpm}$, and serum was separated and stored under $20^{\circ} \mathrm{C}$. Insulin serum levels were measured using a rat insulin enzyme-linked immunosorbent assay (ELISA) kit. A $50 \mu \mathrm{l}$ serum sample added with $50 \mu \mathrm{l}$ biotinylated detection antibody was subsequently incubated for 45 minutes at $37^{\circ} \mathrm{C}$. After being aspirated and washed, the samples were added with $100 \mu$ l Horse dish peroxidase (HRP)-conjugated anti-rabbit IgG prior to incubation at $37^{\circ} \mathrm{C}$ for 30 minutes. Substrate reagent $(90 \mu \mathrm{l})$ was added to the samples and then incubated for 15 minutes at $37^{\circ} \mathrm{C}$. Finally, $50 \mu$ l of 'stop solution' was added into samples which were then read with a microplate reader at $\lambda 450 \mathrm{~nm}$.

\section{Microscopic Preparation of Pancreatic-B Cells}

Pancreatic tissue slices were stained with Hematoxylin Eosin. Using light microscope (400x magnification), the slides were observed for shape, size, and depiction of the number of pancreatic- $\beta$ cells.

\section{Data Analysis}

Data were analyzed by using one-way ANOVA and Least Significant Difference test. $\mathrm{P}<0,05$ was considered to be significant. The data were expressed as means \pm S.E.M

\section{RESULTS}

The Effects of U. lobata Leaf Extract on Body Weight, Food Consumption, Fasting and Random Blood Glucose Levels

In this study, hyperglycemia reduced body weights of diabetic rats (Table 1 ). The extracts of $U$. lobata leaf reduced body weight of diabetic rats, compared with the diabetic group receiving no extracts $(p>0,05)$ (Table 1$)$. The reduction of food consumption was detected in diabetic rats administered with aqueous and hexane extracts of $U$. lobata leaf compared with non-treated diabetic rats $(p<0,05)$ (Table 1$)$. In this study, hyperglycemia did not influence the appetite of diabetic rats receiving no extract and of diabetic rats receiving ethanolic extract of $U$. lobata $(p>0,05)$. The three kinds of $U$. lobata leaf extracts decreased fasting and random blood glucose levels compared to diabetic rats received no extracts $(p<0,05)$. The aqueous extract has lead in reducing fasting and random blood glucose followed by the ethanolic extract, then the hexane extract (Table 1).

The Effects of U. lobata leaf Extract On Insulin Serum Level Of Diabetic Rats

A significant decrease of insulin serum levels ( 14 folds) was shown in diabetic rats compared to normal rats (Fig. 1). Oral administration of $U$. lobata leaf extracts increased 
Table 1. Body weight, food consumption, fasting and random blood glucose levels of male Sprague-Dawley diabetic rats receiving hexane, ethanolic, and aqueous extracts of $U$. lobata leaf

\begin{tabular}{|c|c|c|c|c|c|}
\hline & $\begin{array}{l}\text { Normal } \\
\text { Group }\end{array}$ & $\begin{array}{l}\text { Diabetic } \\
\text { Group }\end{array}$ & HEU & EEU & AEU \\
\hline Body weight (g) & $298,0 \pm 23^{\#}$ & $239,5 \pm 19 *$ & $222,0 \pm 16^{\#}$ & $232,0 \pm 13^{\#}$ & $229,0 \pm 12^{\#}$ \\
\hline Food consumption (g) & $25,0 \pm 0$ & $24,1 \pm 3$ & $21,9 \pm 4^{\#}$ & $24,0 \pm 5$ & $14,2 \pm 3^{\#}$ \\
\hline Food consumption (\%) & $100,0 \pm 0$ & $96,0 \pm 11$ & $87,6 \pm 7^{\#}$ & $96,0 \pm 9$ & $56,0 \pm 6^{\#}$ \\
\hline Fasting blood glucose level (mg/dL) & $101,0 \pm 8^{\#}$ & $129,0 \pm 6 *$ & $96,0 \pm 10^{\#}$ & $92,0 \pm 10^{\#}$ & $87,0 \pm 8^{\#}$ \\
\hline Random blood glucose level (mg/dL) & $127,3 \pm 11^{\#}$ & $176,4 \pm 15^{*}$ & $162,3 \pm 16^{\#}$ & $129,8 \pm 12^{\#}$ & $118,7 \pm 8^{\#}$ \\
\hline
\end{tabular}

Note: Measurements are presented as means \pm SEM $(n=4)$. *Different compared to normal group ( $p<0,05$, LSD test); ${ }^{*}$ Different compared to diabetic group ( $<<0,05$, LSD test); HEU, Hexane extract of $U$. lobata leaf; EEU, Ethanolic extract of $U$. lobata leaf; AEU, Aqueous extract of $U$. lobata leaf.

insulin serum levels. Treatment of hexane and ethanolic $U$. lobata leaf extracts doubled insulin serum level of diabetic rats compared with that of diabetic rats that did not receive the extracts $(p<0,05)$ (Fig. 1).The given dose of aqueous $U$. lobata leaf extract increased insulin serum level almost 5 fold if compared with untreated diabetic rats $(p<0,05)$ (Fig. 1 ).

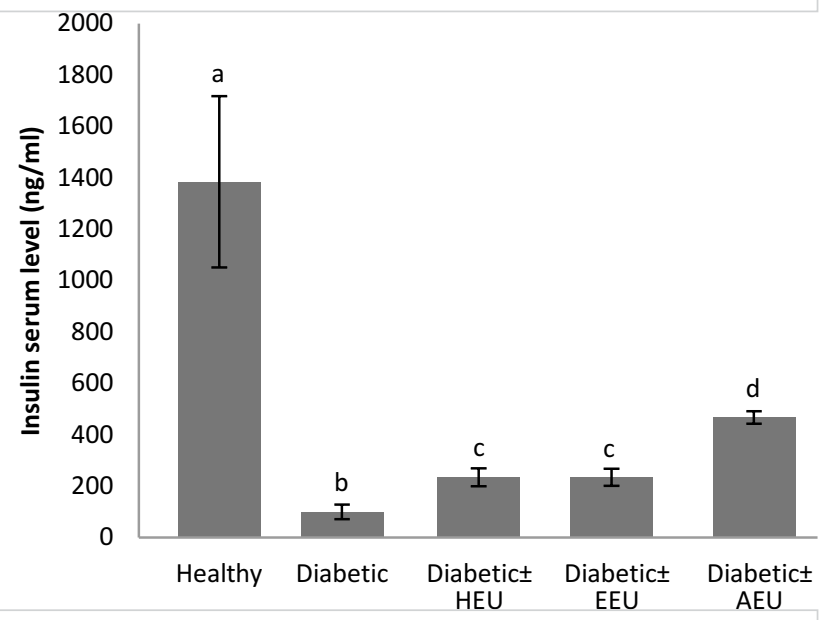

Figure 1. Insulin serum level of diabetic rats received hexane (HEU), ethanolic (EEU), and aqueous (AEU) extracts of $U$. lobata leaf

Note: Measurements are expressed as Means \pm S.E.M. a, b, c: different letter indicates statistically significant difference $(p<0,05)$.

The Effect of U. lobata Extracts on Fasting and Random Blood Glucose Levels, also Glucose Tolerance Test of Diabetic Rats

The $U$. lobata leaf extract reduced fasting and random blood glucose levels of diabetic rats $(p<0,05)$ (Table 1$)$. The area under-glucose tolerance test curve of diabetic rats was significantly corrected in diabetic rats treated with the extract of $U$. lobata leaf (fig. 2). The given dose of aqueous extract of $U$. lobata leaf was the most effective to correct blood glucose level in diabetic rats. At the same dose, the ethanolic extract corrected the blood glucose level close to the blood glucose level of healthy rats ( $p>0,05)$ (Fig. 2). The hexane extract of $U$. lobata leaf reduced blood glucose level significantly compared to the blood glucose level of untreated diabetic rats. Unfortunately, the blood glucose level was still higher than that of the healthy rats $(p<0,05)$ (Fig. 2).

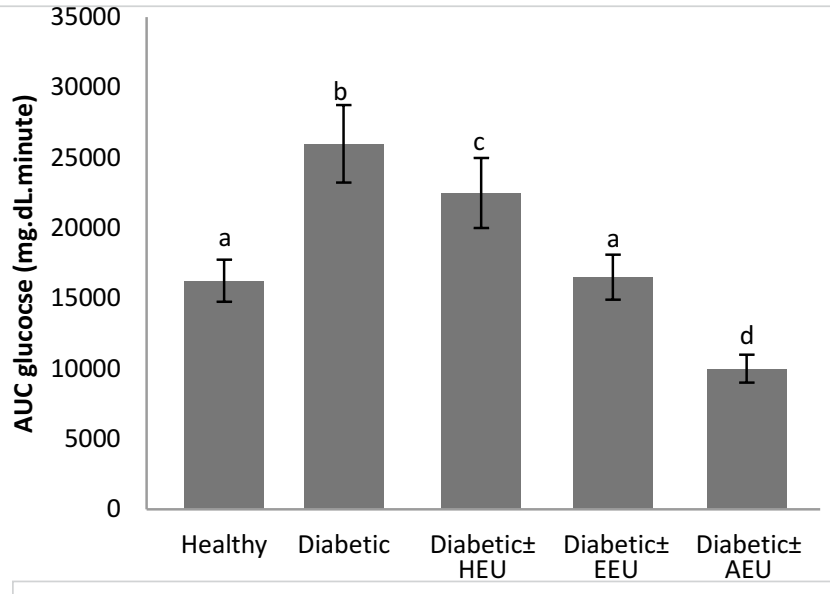

Figure 2. Area under curve of glucose tolerance test graphics of type-2 diabetic rats received hexane (HEU), ethanolic (EEU), and aqueous (AEU) extracts of $U$. lobata

Note: Measurements are expressed as Means \pm S.E.M $(n=4)$. a, b, c: different letter indicates statistically significant difference $(p<0.05)$.

\section{Effect of U. lobata Extracts on Pancreatic B-Cells of Diabetic Rats}

Pancreatic islet $\beta$ cells were examined using light microscope at 400x magnification. Type-2 diabetic rats showed pancreatic islet tissues with small numbers of long shape and unnucleated $\beta$-cells (Fig. 3). The extract of $U$. lobata leaf improved pancreatic islet tissues, the islet $\beta$ cells returned to be round in shape with slightly increased size. There was increased density of islet $\beta$ cells of diabetic rats administered with the extract of the plant compared with that of type-2 diabetic rats. Slightly increased size of islet $\beta$ cells indicated inflammation process in the pancreatic islet tissue (Fig. 3). The islet $\beta$ cells quality of diabetic rats treated with aqueous extract of $U$. lobata was the best. It was shown by the normal shapes and density of islet $\beta$-cells which were proximal to that of healthy rats.

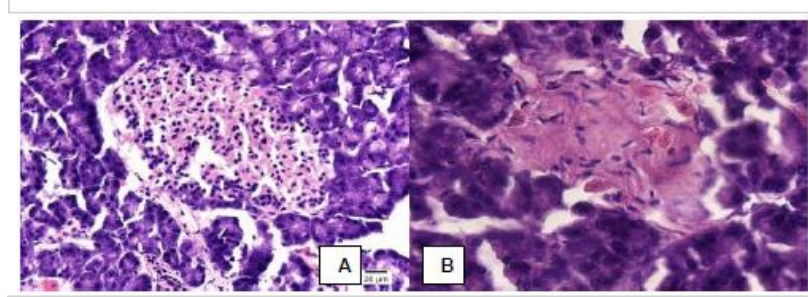

Figure 3. Pancreatic islet $\beta$-cells (HE, 400x, light microscope) 


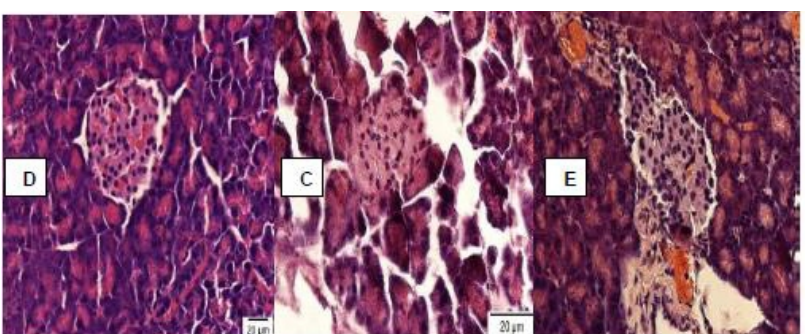

Figure 3. Pancreatic islet $\beta$-cells (HE, 400x, light microscope) (Lanjutan)

Note: (A). Normal group, large numberr of round and nucleated islet $\beta$ cells; (B). Type-2 diabetic group, less number, long shaped and unnucleated cells; (C). HEU-group; less number, round and slightly increase diameter of islet $\beta$-cells. (D). EEU-group; less number, slightly increased diameter of islet $\beta$-cells. (E). AEU-group; slightly increased diameter of islet $\beta$-cells and $\beta$-cells number was proximal to the normal rats. HEU, Hexane extract of $U$. lobata; EEU, Ethanolic extract of $U$. lobata; $\mathrm{AEU}$, Aqueous extract of $U$. lobata.

\section{DISCUSSION}

It was observed that hexane, ethanolic, and aqueous extracts of $U$. lobata leaf reduced the body weight of diabetic rats $(p<0,05)$ compared with diabetic rats received no extract (Table 1 ). The previous study showed aqueous extract of $U$. lobata root significantly reduced the body weight in rabbits (10). Hexane and aqueous extracts of the plant leaf reduced food consumption of diabetic groups, the one treated with aqueous extract exhibited a larger reduction of food consumption $( \pm 56 \%)$. It is suggested that hexane and aqueous extracts of $U$. lobata leaf might have an initial toxic effect. Even though $U$. lobata leaf ethanolic extract decreased body weight of diabetic rats, the extract did not affect the appetite of diabetic rats (Table 1 and Table 2). A modification in duration, frequency, and concentration of treatment may reduce the side effects observed (10). A study reported long-term treatment of aqueous extract of $U$. lobata root toward New Zealand strain weaned rabbits protected the pancreas from oxidative stress (8).

Hexane, Ethanolic, and Aqueous Extracts of U. lobata Leaf Increased Insulin Serum Level and Improved the Condition

\section{of Islet B-Cells of Diabetic Rats}

The extracts of $U$. lobata significantly increased insulin synthesis of type-2 diabetic rats (Fig. 1). The improvement of insulin synthesis was parallel with the condition of pancreatic islet $\beta$-cells as indicated by the increased densities of islet $\beta$-cells (Fig. 1 and Fig. 3). The extracts also prevented islet $\beta$-cells to change in shape (Fig 3). The synergistic interaction of active compounds of $U$. lobata extract is suggested to have a role to increase insulin production (10). The improvement of $\beta$-cells morphology and synergistic interaction of active compounds were strongly suggested to increase insulin release (Fig. 1). A study showed that $U$. lobata used as anti-diabetic did not exert oxidative damage, particularly in the pancreas, the plant were found to be protective against oxidative damage (8). It is recognized that insulin secretion depends on $\beta$-cells number and function, autonomic innervation of pancreas, and endocrine regulation of islet function (1315). A potent insulinotropic hormone, Glucagon-like peptide-1 (GLP-1), is released by oral glucose as well as ingestion of mixed meals, the hormone is rapidly metabolized by Dipeptidyl peptidase (DPP) IV (12). In silico study reported that DPP IV activity was inhibited by aqueous and ethanolic extrats of $U$. lobata, it was supposed that bioactive compound of $U$. lobata may have a property of DPP-IV inhibitor (7). Hormone GLP-1 inhibits gastric juice secretion and gastric motility, the later slows gastric emptying rate and prolongs the transportation of gastric juice into the gut that consequently prevents the absorption of glucose (16). This study showed diabetic rats treated with aqueous extract of $U$. lobata produced insulin more than the ones treated with hexane or ethanolic extract of $U$. lobata (Fig. 1), the results lead to a suggestion that water is the suitable solvent for any $U$. lobata bioactive agents concerning with insulin production. Pancreatic islet histology concerning shape and size of islet $\beta$-cells of diabetic rats received the aqueous extract of $U$. lobata was in conformity with its insulin production (Fig. 1 and Fig. 3).

The main chemical groups of bioactive compounds in plants are glycosides, tannins, flavonoids, saponins, terpenoids, resins, lignans, alkaloids, furocoumarins,

Table 2. Effects of hexane, ethanolic, and aqueous extracts of $U$. lobata leaf on diabetic male SD rats

\begin{tabular}{|c|c|c|c|c|c|c|c|}
\hline SD Rats & BW(\%) & FC (\%) & $\begin{array}{c}\text { Insulin } \\
\text { Serum } \\
\text { Level (\%) } \\
\end{array}$ & $\begin{array}{l}\text { AUC } \\
(\%)\end{array}$ & $\begin{array}{l}\text { FBG } \\
\text { (\%) }\end{array}$ & $\begin{array}{l}\text { RBG } \\
(\%)\end{array}$ & $\begin{array}{l}\text { Microscopic } \\
\text { islet } \beta \text {-cells }\end{array}$ \\
\hline $\begin{array}{l}\text { Healthy } \\
\text { (Normal) }\end{array}$ & $100,0 \pm 0$ & $100,0 \pm 0$ & $100,0 \pm 0$ & $100,0 \pm 0$ & $100,0 \pm 0$ & $100,0 \pm 0$ & $\begin{array}{l}\text { round, normal size } \\
\text { nucleated, } \\
\text { normal number }\end{array}$ \\
\hline Diabetic & $80,36 \pm 6,37$ & $96,0 \pm 11$ & $7,14 \pm 2,38$ & $162,50 \pm 18,46$ & $127,72 \pm 5,94$ & $128,57 \pm 11,78$ & $\begin{array}{l}\text { long, unnucleated, } \\
\text { less number }\end{array}$ \\
\hline $\begin{array}{l}\text { Diabetic } \\
+\mathrm{HEU}\end{array}$ & $74,49 \pm 5,36$ & $87,6 \pm 7$ & $14,28 \pm 3,57$ & $140,63 \pm 15,38$ & $95,04 \pm 9,90$ & $127,49 \pm 12,56$ & $\begin{array}{l}\text { round, } \\
\text { nucleated, } \\
\text { increased diameter, } \\
\text { less number }\end{array}$ \\
\hline $\begin{array}{l}\text { Diabetic } \\
+ \text { EEU }\end{array}$ & $77,85 \pm 4,36$ & $96,0 \pm 9$ & $16,66 \pm 2,38$ & $101,53 \pm 10,76$ & $91,09 \pm 9,90$ & $101,96 \pm 9,42$ & $\begin{array}{l}\text { round, } \\
\text { nucleated, } \\
\text { increased diameter, } \\
\text { less number }\end{array}$ \\
\hline $\begin{array}{l}\text { Diabetic } \\
+\mathrm{AEU}\end{array}$ & $76,84 \pm 4,02$ & $56,0 \pm 6$ & $32,14 \pm 1,78$ & $62,50 \pm 6,15$ & $86,13 \pm 7,92$ & $93,24 \pm 6,28$ & $\begin{array}{l}\text { round, } \\
\text { increased diameter, } \\
\text { normal number }\end{array}$ \\
\hline
\end{tabular}

Note: Measurements are expressed as means \pm S.E.M ( $n=4)$. SD, Sprague-Dawley; BW, Body weight; FC, Food Consumption; AUC, Area Under Curve of Glucose Tolerance Test Graphics; FBG, Fasting Blood Glucose Level: RBG, Random Blood Glucose Level. 
protein, and peptides (17). Flavonoids consist of six major groups namely flavone, chalcone, flavonol, flavonone, anthocyanin \& iso-flavonone (18). Urena lobata leaf extracted by petroleum ether continued with methyl alcohol result in 4 types of flavonoids, i.e. kaempferol, quercetin, kaempferol 3-O-beta glucopyranoside, and quercetin 3-O-rutinoside (19). A portion of ethyl acetate and n-butanol of $95 \%$ ethanolic extract of branches and leaf showed ten flavonoid compounds, i.e. kaempferol, rutin, quercetin, afzelin, astragalin, tiliroside, kaempferol3-O- $\beta$-D-glycopyranoside-7-O- $\alpha$-L-rhamnoside, kaempferol-7-O- $\alpha$-L-rhamnoside, kaempferol-7-O- $\alpha-L-$ rhamnoside-4'-O- $\beta$-D-glycopyranoside, and crenuloside (2). All flavonoids are usually water soluble and are responsible for various biological and pharmacological activities in mammals, most importantly their antioxidant activities (20). A study reported that markers for oxidative stress, 8-hydroxy-2'-deoxyguanosine (8-OHdG) and 4hydroxy-2-nonenal (HNE)-modified protein, were increased in the pancreatic $\beta$-cells of non-obese diabetic rats (21). The present study showed morphology improvement of islet $\beta$-cells of diabetic rats, and it is suggested that flavonoids of $U$. lobata extract play a role in improving the condition of pancreatic islet $\beta$-cells.

The Extracts of U. lobata Leaf Corrected the Blood Glucose Level of Diabetic Rats

Hyperglycemia results in oxidative stress leading to oxidative damage of organs and increases of diabetic complication risk (22). Since antioxidant enzymes are low expressed in pancreatic islet, consequently $\beta$-cells are in a susceptible condition to face chronic oxidative stress due to hyperglycemia (23). Study on GK-rats (type 2 diabetic model) showed that chronic hyperglycemia might be responsible for oxidative stress in pancreatic islet $\beta$-cells of rats (21). Long-term treatment of aqueous extract of $U$. lobata leaf in the weaned rabbits followed by evaluation of oxidative status reported that SOD and catalase activities in the serum and tissue of the rabbits were generally higher or statistically similar to the control; the serum, liver, and pancreatic MDA levels were significantly decreased; the study showed the hypoglycemic medicinal plants did not exert oxidative damage; particularly in the pancreas, they were found to be protective against oxidative damage (8).

This study showed $U$. lobata leaf extracts corrected the OGTTs and its AUCs. Ethanolic extract of U. lobata leaf at a dose of $500 \mathrm{mg} / \mathrm{kgBW}$ was optimal to correct the blood glucose level, it was statistically proximity with normal rats (Fig. 2). This result accompanied with insulin serum level at $17 \%$ of the normal rats or the level was about over twofold if compared with diabetic rats (Fig. 1 and Table 2). There were no changes in food consumption of diabetic

\section{REFERENCES}

1. Uddin MB, Steinbauer MJ, Jentsch A, Mukul SA, and Beierkuhnlein C. Do Environmental Attributes, Disturbances and Protection Regimes Determine the Distribution of Exotic Plant Species in Bangladesh Forest Ecosystem? Forest Ecology and Management. 2013; 303: 72-80.

2. Ali SL, Babu SS, and Madhuri DB. A Pharmacological Review of Urena lobata Plant. Asian Journal Pharmaceutical and Clinical Research. 2016; 9(2): 20-22. rats received the ethanolic extract of $U$. lobata leaf (Table 1 and Table 2).

The studies of aqueous extract of the plant leaf in STZ induced-diabetic rats showed significant hypoglycemic effects $(5,7)$. Our study found that aqueous extract of $U$. lobata leaf at a dose of $500 \mathrm{mg} / \mathrm{kgBW}$ dropped blood glucose level by $40 \%$ beneath the blood glucose level of normal rats (Table 1 and Fig. 2); the aqueous extract of the leaf increased almost 5 -fold the insulin serum level compared with untreated diabetic rats, or the insulin increment was up to $30 \%$ insulin level in normal rats (Fig. 1 and Table 2); the results were accompanied with body weight and appetite loss (Table 1 and Table 2). The dropped blood glucose level might have been caused by the loss of appetite. Metformin, GLP-1 mimetic (Exenatide), and amylin analog (Pramlitide) are oral anti-diabetics accompanied by body weight loss (24). The diabetic rats received aqueous leaf extract were detected to have the lowest fasting and random blood sugar levels (Table 1 and Table 2).

Hexane extract of $U$. lobata leaf reduced blood glucose level by only approximately $29 \%$ of blood glucose level in diabetic rats and it was still over $40 \%$ higher than blood glucose level in normal rats (Table 2); the insulin serum level was about somewhat similar with the insulin level of diabetic rats treated with ethanolic extract of $U$. lobata leaf (Fig. 1 and Table 2); there were loss of body weight and reduction of food consumption of the animals (Table 1 and Table 2). The study on antioxidant effects of $n$-hexane fraction of $U$. lobata showed no reactions (25).

Hexane, ethanolic, and aqueous extracts of $U$. lobata leaf improved insulin serum level and improved the morphology of pancreatic islet $\beta$-cells. The extracts corrected oral glucose tolerance tests and its area under curves. Aqueous extract of $U$. lobata leaf showed the best performance in increasing insulin and recovering islet $\beta$ cells condition. The ethanolic extract showed the best result in correcting the blood glucose level. The hexane extract of $U$. lobata leaf showed poor result in correcting the blood glucose level.

\section{Acknowledgment}

We acknowledge the study was supported by the Ministry of Research, Technology, and Higher Education of Indonesia, based on letter agreement NO. 114/B.07/U.V/LPPM/2016, May 13,2016

\section{Conflicts of Interest}

The authors declare that there are no conflicts of interests regarding the publication of this article.
3. Dhanapal R, Ratna JV, Gupta M, and Sarathchandran I. Preliminary Study on Antifertility Activity of Enicostemma Axillare Leaves and Urena lobata Root Used in Indian Traditional Folk Medicine. Asian Pacific Journal of Tropical Medicine. 2012; 5(8): 616-622.

4. Mazumder UK, Gupta M, Manikandan L, and Bhattacharya S. Antibacterial Activity of Urena lobata Root. Fitoterapia. 2001; 72(8): 927-929.

5. Onoagbe IO, Negbenor EO, Ogbeide VO, et al. A Study of the Anti-diabetic Effects of Urena lobata and 
Sphnenostylis stenocarpa in Streptozocin-induced Diabetic Rats. European Journal of Science and Research. 2010; 43(1): 6-14.

6. Islam MT, Ibrahim M, Ahsan MQ, Chowdhury MMU, Hossain MA, and Rashid MA. Phytochemical and Pharmacological Investigations of Uraria lagopodies $D C$. and Urena lobata L. Dhaka University Journal of Pharmaceutical Science. 2012; 11(1): 65-69.

7. Purnomo Y, Soeatmadji DW, Sumitro SB, and Widodo MA. Anti-diabetic Potential of Urena lobata Leaf Extract through Inhibition of Dipeptidyl Peptidase IV Activity. Asian Pacific Journal of Tropical Biomedicine. 2015; 5(8): 645-649.

8. Omonkhua AA and Onoagbe IO. Long-term Effects of Three Hypoglycaemic Plants (Irvingia Gabonensis, Urena Lobata and Carica Papaya) on the Oxidative Status of Normal Rabbits. Biokemistri. 2012; 24(2): 82-89.

9. Sipai BS, Bindu MD, and Subba RD. Anxiolytic Antidepressant and Anti-Inflammatory. International Journal of Pharma Research and Health Science. 2016; 4(4): 1284-1290.

10. Mathappan R, Prasanth VV, Jolly Cl, and Somanath M. Comparative Study on the Antibacterial Activity of the Methanolic Extract of Urena Lobata Root and a Standard Marketed Herbal Formulation. Journal of Pharmaceutical Research. 2010; 3(5): 953.

11. Togashi Y, Shirakawa J, Okuyama T, et al. Evaluation of the Appropriateness of Using Glucometers for Measuring the Blood Glucose Levels in Mice. Scientific Reports. 2016; 6: 1-9.

12. Schwartz S. Evidence-Based Practice Use of IncretinBased Therapy in the Natural History of Diabetes. Postgraduate Medicine. 2014; 126(3): 66-84.

13. Hoang DO and Thorn P. Insulin Secretion from Beta Cells within Intact Islets: Location Matters. Clinical and Experimental Pharmacology and Physiology. 2015; 42(4): 406-414.

14. Punjabi P, Mathur P, Gupta RC, et al. Autonomic Dysfunction in Asian Indian T2DM Patients is Related to Body Fat Content Instead of Insulin Resistance: A DEXA Study. Journal of Basic \& Applied Sciences. 2014: 10; 212-219.

15. Molina J, Rodriguez-Diaz R, Fachado A, Jacques-Silva
MC, Berggren PO, and Caicedo A. Control of Insulin Secretion by Cholinergic Signaling in the Human Pancreatic Islet. Diabetes. 2014; 63(8): 2714-2726.

16. Edholm T, Degerblad M, Gryback P, et al. Differential Incretin Effects of GIP and GLP-1 on Gastric Emptying, Appetite, and Insulin-Glucose Homeostasis. Neurogastroenterology and Motility. 2010; 22(11): 1191-1200.

17. Bernhoft A. Bioactive Compounds in Plants: Benefits and Risks for Man and Animals. Proceedings from a Symposium Held in Norwegian Academy of Science and Letters. Oslo, November 13-14, 2008.

18. Ndam LM, Mih AM, Fongod AGN, et al. Phytochemical Screening of the Bioactive Compounds in Twenty (20) Cameroonian Medicinal Plants. International Journal of Current Microbiology and Applied Science. 2014; 3(12): 768-778.

19. Singh D and Singh VS. Isolation and Characterization of Flavonoids in Urena lobata Leaves. European Journal of Medicinal Plants. 2016; 11(1): 1-6.

20. Chebil L, Humeau C, Anthoni J, Dehez F, Engasser JM, and Ghoul M. Solubility of Flavonoids in Organic Solvents. Journal of Chemical and Engineering Data. 2007; 52(5): 1552-1556.

21. Ihara Y, Toyokuni S, Uchida K, et al. Hyperglycemia Causes Oxidative Stress in Pancreatic $B$ Cells of GK Rats, a Model of Type2 Diabetes. Diabetes. 1999; 48(4): 927-932.

22. Kawahito S, Kitahata H, and Oshita S. Problems Associated with Glucose Toxicity: Role of Hyperglycemia-Induced Oxidative Stress. World Journal of Gastroenterology. 2009; 15(33): 4137-4142.

23. Lenzen S, Drinkgren J, and Tiedge M. Low Antioxidant Enzyme Gene Expression in Pancreatic Islets Compared with Various Other Mouse Tissues. Free Radical Biological Medicine. 1996; 20(3): 463-466.

24. Hollander P. Anti-Diabetes and Anti-Obesity Medications: Effects on Weight in People with Diabetes. Diabetes Spectrum. 2007; 20(3): 160-165.

25. Adewale AO, David AK, Abiodun OO, and Craig OA. Studies on Antimicrobial, Antioxidant, and Phytochemical Analysis of Urena lobata Leaves Extract. Journal of Physical and Natural Science. 2007; 1(2): 1-9. 